\title{
33 Long-term care insurance and the family: does the availability of potential caregivers substitute for long-term care insurance?
}

\footnotetext{
- Children and especially daughters play an important role in the supply of informal care

- The availability of potential informal caregivers, i.e. the children, decreases the probability of purchasing private voluntary long-term care insurance

- Future research on long-term care should focus on characteristics of potential substitutes for insurance policies (children and partner)
}

\subsection{Why long-term care is an issue in Europe}

The needs for long-term care (LTC) are expected to increase gradually due to population ageing in Europe. The population aged 65 or older, which is more at risk of dependency, will more than double by 2050 according to the forecasts of the European Union (Pestieau \& Ponthière 2010). It is however unclear if the population in need for care will increase in the same proportion due to compression of morbidity (potential increase of life expectancy in good health). In assessing the adequacy of the financing and provision of long-term care, it is important to take into account the abilities of the countries to rely on the informal provision of care to older individuals in the future. Recent studies, using inter alia SHARE data (e.g. Bolin et al. 2008), showed that long-term care is mainly provided by informal caregivers. This type of care has no direct impact on public finances but it is not clear if such a situation is desirable. Several studies have highlighted that caregivers bear large opportunity costs because of care responsibilities (e.g. Van Houtven et al. 2013). Furthermore, informal care may have adverse effects on multiple dimensions of health of the caregivers (Pinquart \& Sörensen 2003). The propensity to provide care could decrease due to changes in family structure and the growing participation of women in the labour market, which may constrain the future supply of informal care provision within the family (Pestieau \& Ponthière 2010). Moreover, the low rates of public long-term care insurance (LTCI) coverage could lead to adverse financial consequences for older individuals and their families. Estimates suggest that the cost of a one-year stay in a nursing 
home averages between $\$ 40,000$ and $\$ 50,000$ a year in the United States while a 65-year-old has 39 per cent chance of entering a nursing home (Mellor 2001). A potential solution to this lack of public coverage could be the development of private insurance market for long-term care. This alternative depends on the suitability of a market solution for this type of insurance. United States, France, Japan, Germany and Israel are the countries where this market insurance is the most present (Colombo et al. 2011; see also chapter 32 in this volume). Recent market developments in some OECD countries suggest that insurance providers are moving more and more towards private LTC indemnity policies (Colombo et al. 2011). However, this sector is likely to remain small compared to public insurance. Brown and Finkelstein (2007) provided evidence of supply side market failures (premiums marked up substantially above expected benefits and coverage limit relative to the total expenditure risk). Pestieau and Ponthière (2010) focused also on the causes of the "long-term care insurance puzzle". They identified six potential explanations for the underdevelopment of the private LTCI market: excessive costs - loading factors and adverse selection -, social assistance acting as a Good Samaritan, trust into family solidarity, unattractive rule of reimbursement - lump sum -, myopia or ignorance, and denial of heavy dependence.

Regarding the trust in family solidarity, Pauly (1990) developed a theoretical framework highlighting the importance of children in the rationale for the non-purchase of LTCI due to intra-family moral hazard. If parents prefer receiving care from children, they are less likely to opt for LTCI. Mellor (2001) tested this hypothesis of parents relying on child-provided care in old-age in United States: while education, income and wealth impact positively on LTCI ownership (consistent with Brown \& Finkelstein 2007), she found no evidence of a significant link between the availability of informal caregivers and insurance ownership. Thanks to the 1st wave of SHARE in France, Courbage and Roudaut (2011) showed that LTCI is purchased to protect families, in order to prevent children from heavy tasks given the evidence about potential negative effects associated with the caregiving burden.

The 5th wave of SHARE introduced questions about the ownership of voluntary/supplementary LTCI. The potential substitutability between informal care providers (children and partner) and private LTCI can be tested empirically for several SHARE countries. Section 33.2 presents the analytical sample, taking into account the countries where private voluntary/supplementary LTCI is in place. Section 33.3 confirms that LTC is largely provided informally and more specifically by daughters. Section 33.4 suggests a significant relationship between the availability of informal caregivers and LTCI ownership. Section 33.5 concludes. 


\subsection{Long-term care insurance in SHARE Wave 5}

In Wave 5, a new question appeared in the SHARE questionnaire: "Do you have any of the following public or private long-term care insurances?”. The choices were: "1. Public; 2. Private mandatory; 3. Private voluntary/supplementary; 96. None”. Respondents could select as many answers as they want. The summary of the respondent's answers is in Table 33.1. It is important to note the absence of Germany, Sweden, Belgium and Slovenia due to data collection problems and the large proportion of "None" and "Do not know" answers" while in all SHARE countries, basic coverage of LTC exists, sometimes implicitly in national basic health insurance. Indeed, LTC are partially covered by the national health systems. In Luxembourg support for the provision of LTC, either at home or in an institution, is mainly provided through the universal long-term care insurance ("assurance dépendance") as part of the social security scheme. The public health insurance system of Belgium (INAMI/RIZIV) provides a comprehensive universal coverage for all costs associated with acquiring assistance for activities of daily living (dressing, eating, washing, etc.). This benefit applies to assistance provided both at home and in institutions, subject to personal contributions (i.e. "ticket modérateur"). Different measures exist to minimise out-of-pocket payments. The federal allowances for the older individuals and targeted social welfare benefits are financed through direct general taxation. Finally, according to the Swiss health accounts, long-term care is financed for about 40 per cent through a complex system of public support and social insurance and about 60 per cent by household. Public LTC expenditure varies from 0.5 per cent of GDP in Estonia to 3.8 per cent of GDP in the Netherlands and even 4.5 per cent in Denmark (European Union 2012).

The sum of the percentages of the Table 33.1 can be larger than one hundred since the respondents can benefit from public insurance and take a supplementary one to be better covered.

However, the interest of this chapter is on the voluntary LTCI ownership. Colombo et al. (2011) explain that "typically, private LTC insurance arrangements develop around a country's public LTC system, either to complement available public coverage, or provide benefits where there is no public LTC coverage.” There are two types of private LTC products: the model of reimbursement (US/Germany) and the indemnity model (France/Germany). Germany has therefore the two types of private LTCI. A compulsory one for individuals who have opted out of social health insurance ( $9 \%$ of population, reimbursement) and a voluntary one which insures eligible expenses not covered by the LTCI programme $3.5 \%$ of population, indemnity policies) (Colombo et al. 2011).

1 Only 0.19 per cent of respondents refuse to answer the question 
Table 33.1: Long-term care insurance in SHARE Wave 5 countries

\begin{tabular}{llcllll}
\hline Country & $\begin{array}{l}\text { Obser- } \\
\text { vations } \\
\text { (\#) }\end{array}$ & $\begin{array}{l}\text { Public } \\
\text { (\%) }\end{array}$ & $\begin{array}{l}\text { Private } \\
\text { mandatory } \\
\text { (\%) }\end{array}$ & $\begin{array}{l}\text { Private } \\
\text { voluntary/ } \\
\text { supple- } \\
\text { mentary } \\
\text { (\%) }\end{array}$ & $\begin{array}{l}\text { None } \\
(\%)\end{array}$ & $\begin{array}{l}\text { Do not } \\
\text { know } \\
\text { (\%) }\end{array}$ \\
\hline DK & 4,127 & 25.2 & 0.0 & 1.9 & 72.6 & 0.3 \\
LU & 1,610 & 88.7 & 4.9 & 11.2 & 7.8 & 0.4 \\
NL & 4,094 & 27.6 & 32.4 & 14.0 & 26.2 & 5.2 \\
FR & 4,412 & 0.0 & 2.7 & 15.5 & 81.2 & 0.8 \\
CH & 3,005 & 0.0 & 0.0 & 18.6 & 74.9 & 6.6 \\
AT & 4,251 & 0.0 & 0.0 & 1.4 & 98.2 & 0.5 \\
ES & 6,451 & 26.0 & 0.6 & 5.1 & 70.2 & 0.6 \\
IT & 4,702 & 10.2 & 0.7 & 2.2 & 86.8 & 0.5 \\
EE & 5,721 & 6.8 & 0.1 & 0.1 & 92.5 & 0.5 \\
CZ & 5,655 & 39.7 & 1.2 & 1.8 & 56.0 & 1.5 \\
IL & 2,433 & 0.0 & 61.4 & 29.6 & 26.9 & 5.6 \\
\hline Total & 46,471 & 18.44 & 9.08 & 8.87 & 64.5 & 1.3 \\
\hline
\end{tabular}

Notes: Excluding Germany, Sweden, Belgium and Slovenia for spurious or missing data Source: SHARE Wave 5 release 0

The countries included in the analysis are the ones for which there is a private market for LTCI. According to Colombo et al. (2011) and the results from Table 33.1, nine countries have been selected. All citizens from Denmark, Luxemburg, the Netherlands, France, Switzerland, Austria, Spain, Italy, the Czech Republic and Israel have the possibility to purchase voluntary LTCI. However, Spain is not included in the sample because private LTCI seems to be reported too frequently. Sweden is also excluded from the sample since the question was not correctly phrased (it refers to "private health care policy" rather than "private LTC policy", see chapter 32 in this volume for the reliability of answers to LTCI question). Citizens from Luxemburg, Switzerland and the Netherlands seem also to overestimate their private intake of LTCI. However, they remain in the sample since the well-established presence of this market and a rate of private insurance ownership higher than ten per cent. Estonia is removed from the sample given the extremely low percentage of respondents $(0.1 \%)$ reporting owning a voluntary insurance. 
Table 33.2: Summary statistics

\begin{tabular}{lllllllll}
\hline Country & $\begin{array}{l}\text { Obs } \\
\text { (\#) }\end{array}$ & $\begin{array}{l}\text { Informal } \\
\text { care } \\
(\%)\end{array}$ & $\begin{array}{l}\text { Private } \\
\text { LTCI } \\
(\%)\end{array}$ & $\begin{array}{l}\text { Woman } \\
\text { (\%) }\end{array}$ & $\begin{array}{l}\text { Single } \\
\text { (\%) }\end{array}$ & $\begin{array}{l}\text { 1 child } \\
\text { (\%) }\end{array}$ & \# Sons & \# Daughters \\
\hline DK & 4,045 & 27.2 & 1.9 & 53.5 & 29.2 & 92.0 & 1.16 & 1.14 \\
LU & 1,592 & 15.0 & 11.2 & 52.8 & 25.2 & 87.2 & 1.03 & 0.94 \\
NL & 4,054 & 15.0 & 14.0 & 55.0 & 22.6 & 89.3 & 1.17 & 1.14 \\
FR & 4,339 & 13.1 & 15.5 & 56.9 & 35.2 & 89.7 & 1.17 & 1.11 \\
CH & 2,956 & 13.1 & 18.6 & 54.4 & 29.5 & 83.5 & 1.05 & 1.03 \\
AT & 4,177 & 19.0 & 1.4 & 57.4 & 37.5 & 88.0 & 1.08 & 1.05 \\
IT & 4,622 & 13.6 & 2.2 & 54.4 & 22.3 & 87.6 & 1.03 & 0.93 \\
CZ & 5,570 & 34.7 & 1.8 & 58.5 & 36.0 & 95.4 & 1.1 & 1.08 \\
IL & 2,401 & 16.2 & 29.6 & 56.0 & 22.5 & 92.8 & 1.52 & 1.47 \\
\hline Total & 33,756 & 19.7 & 8.9 & 55.8 & 29.7 & 89.9 & 1.13 & 1.09 \\
\hline
\end{tabular}

Notes: Excluding individuals being less than 50 years old

Source: SHARE Wave 5 release 0

For the other countries, the market for LTCI is still in its infancy. ${ }^{2}$ Table 33.2 presents the summary statistics for the main variables from the fifth wave of SHARE used in the models. The sample includes respondents aged 50 or older since the intake of insurance should be before the moment where dependency occurs (no age restriction).

\subsection{The importance of children in informal care supply}

Before looking at the availability of informal caregivers and LTCI ownership, we provide evidence that children play a significant role in providing informal care, particularly daughters. Table 33.3 presents the results from three models estimating the determinants of the probability to receive informal care from anyone outside the household, i.e. children (in-law), friends, neighbour, other relative, etc. The sample sizes for the analysis vary as compared to that of summary statistics due to missing information on educational level of respondents and/or distance from the nearest child. The measure of informal care is based on the fol-

2 For Belgium and Slovenia, problems in the collection of data occurred. Germany is also not in the sample because of non-response, although the possibility of purchasing LTCI exists. 
lowing question: "Thinking about the last twelve months has any family member from outside the household, has any friend or neighbour given you or your partner personal care or practical household help?". The models include the following explanatory variables: the number of sons and the number of daughters, gender, age, a dummy variable that is equal to one if the respondent has a partner (married or not), a dummy variable that is equal to one if the respondent has still a child in the household. In order to measure the disability of the respondents, we built a disability index based on the first principal component identified from a principal component analysis (PCA) depending on the five following measures: having more than one chronic disease, have more than three mobility problems, having more than one (instrumental) daily activity limitation and being considered as depressed according to the EURO-D scale. This depression scale has been created by a collaboration of eleven European countries to allow comparison of risk factor profiles. The PCA is done for each country separately. We also add the distance from the nearest child in the models as some studies have shown that it is related to the probability to receive informal care (e.g. Bonsang 2009) ${ }^{3}$. Finally, we include education level of the respondent: low education corresponds to ISCED 0 to ISCED 2 (lower secondary school), medium education corresponds to ISCED 3 (upper secondary school), and high education corresponds to ISCED 4 (post-secondary non tertiary school) to ISCED 6.

The estimates of the marginal effect (at the sample mean) reported in the first column (1) are based on a sample including all respondents without taking into account the geographical distance from the nearest child, and irrespective of whether they have children. In SHARE, this child location variable is allowed to take the following categories: the children can live either in the same building (but not the same household), less than one $\mathrm{km}$ away, between one and five $\mathrm{km}$ away, between five and $25 \mathrm{~km}$ away, between 25 and $100 \mathrm{~km}$ away, between 100 and $500 \mathrm{~km}$ away or more than $500 \mathrm{~km}$ away. From this variable, we compute a new variable, the distance from the nearest child, by assigning the number of kilometres corresponding to the middle of the bandwidth of each possible categorical answer. The second (2) and the third (3) columns are different from the first one because the sample includes now respondents with at least one child living outside of the household. The distance from the nearest child is added as an additional explanatory variable. While the second model includes all respondents, the third specification focuses on individuals aged 65 years or more.

31,405 respondents are dropped from the sample due to missing information about the distance from the nearest child 
In all models, the number of children is a significant factor predicting the probability to receive informal care. Having daughters seems more helpful for receiving care than having sons. Having a partner highly decreases the probability to receive informal care by people living outside of the household. Moreover, we observe that women have a higher probability of receiving care from outside the household. Disability, as a proxy for the need for care, is also a significant predictor for receiving informal care. Having a co-resident child is also associated with a lower probability to receive informal care from outside the household, suggesting the importance of intra-household care provision as substitute for care received from outside the household. Finally, geographical distance from the children is negatively associated with the probability to receive informal care.

Table 33.3: Probability of receiving informal care from outside the household

\begin{tabular}{|c|c|c|c|c|c|c|}
\hline Variables & $\begin{array}{l}\text { (1) Probit } \\
\text { Marginal } \\
\text { effects }\end{array}$ & $\begin{array}{l}\text { Standard } \\
\text { error }\end{array}$ & $\begin{array}{l}\text { (2) Probit } \\
\text { Marginal } \\
\text { effects }\end{array}$ & $\begin{array}{l}\text { Standard } \\
\text { error }\end{array}$ & $\begin{array}{l}\text { (3) Probit } \\
\text { Marginal } \\
\text { effects }\end{array}$ & $\begin{array}{l}\text { Standard } \\
\text { error }\end{array}$ \\
\hline Number of sons & $0.005^{\star \star}$ & $(0.002)$ & $0.006^{\star \star \star}$ & $(0.002)$ & $0.008^{\star \star}$ & $(0.003)$ \\
\hline Number of daughters & $0.010^{\star \star \star}$ & $(0.002)$ & $0.011^{\star \star \star}$ & $(0.002)$ & $0.013^{\star \star \star}$ & $(0.003)$ \\
\hline Having a partner & $-0.082^{\star \star \star}$ & $(0.005)$ & $-0.084^{\star \star \star}$ & $(0.006)$ & $-0.093^{\star \star *}$ & $(0.008)$ \\
\hline $\begin{array}{l}\text { One child in } \mathrm{HH} \\
\text { Distance from the } \\
\text { nearest child }\end{array}$ & - & - & $-0.027^{\star \star \star}$ & $(0.007)$ & $-0.049^{\star \star \star}$ & $(0.010)$ \\
\hline$(\mathrm{km} / 100)$ & - & - & $-0.006^{\star \star \star}$ & $(0.002)$ & $-0.009^{\star \star \star}$ & $(0.003)$ \\
\hline Disability & $0.054^{\star \star \star}$ & $(0.001)$ & $0.056^{\star \star \star}$ & $(0.002)$ & $0.064^{\star \star \star}$ & $(0.002)$ \\
\hline Female & $0.011^{\star \star}$ & $(0.004)$ & $0.012^{\star \star}$ & $(0.005)$ & $0.020^{\star \star \star}$ & $(0.007)$ \\
\hline Low education & Ref. & Ref. & Ref. & Ref. & Ref. & Ref. \\
\hline Medium Education & 0.008 & $(0.005)$ & 0.008 & $(0.006)$ & 0.001 & $(0.008)$ \\
\hline High Education & $0.021^{\star \star \star}$ & $(0.006)$ & $0.027^{\star \star \star}$ & $(0.007)$ & 0.011 & $(0.010)$ \\
\hline Aged 50-64 & -0.001 & $(0.005)$ & 0.004 & $(0.006)$ & - & - \\
\hline Aged 65-74 & Ref. & Ref. & Ref. & Ref. & Ref. & Ref. \\
\hline Aged $75-84$ & $0.058^{\star \star \star}$ & $(0.007)$ & $0.058^{\star \star \star}$ & $(0.008)$ & $0.056^{\star \star \star}$ & $(0.008)$ \\
\hline Aged $85+$ & $0.125^{\star \star \star}$ & $(0.012)$ & 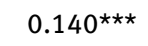 & $(0.014)$ & $0.135^{\star \star \star}$ & $(0.015)$ \\
\hline Observations & \multicolumn{2}{|c|}{33,600} & \multicolumn{2}{|c|}{26,802} & \multicolumn{2}{|c|}{15,899} \\
\hline Log likelihood & \multicolumn{2}{|c|}{$-14,646$} & \multicolumn{2}{|c|}{$-11,932$} & \multicolumn{2}{|c|}{$-7,495$} \\
\hline
\end{tabular}

Significance: ${ }^{\star \star \star}=1 \% ;{ }^{* \star}=5 \% ;{ }^{*}=10 \%$

Notes: Country dummies are also included in the model; The first column presents the results of the model using the full sample, the second column only includes individuals with at least one child living out of the household, and the third column is restricted to individuals with at least one child living out of the household and being less than 65 year-old Source: SHARE Wave 5 release 0 
We assessed the robustness of our results by estimating the model using different specifications and analytical samples. The two analysis presented in columns 2 and 3 were performed on singles only. The number of children was limited to four. Wealth and income obtained from the previous wave of SHARE were included in the analysis (Luxemburg and Israel were dropped from the sample in these models because they were not part of W4). In all cases, children (and especially daughters) play a significant role in the provision of informal care to older parents.

\subsection{The availability of informal caregivers and long-term care insurance ownership}

In the previous section, we provide evidence about the importance of children in informal care provision from outside the household. If having a child is negatively linked to the probability to own a LTCI that could be consistent with the concept of substitutability of children to LTCI purchase.

Table 33.4 shows the estimates of the marginal effects (at the sample mean) of the probability of "owning voluntary private long-term care insurance". For the first model, the analysis is based on a sample including all respondents without taking into account the geographical distance from the nearest child, and irrespective of whether they have children. The number of sons and daughters has a negative impact on the probability of owning a private voluntary LTCI. We add the restriction of having at least one child living outside of the household in the second probit model (2). The role of children is still significant (the daughters are slightly better substitutes than sons), and the same applies if a child lives in the household. Having a partner now decreases the probability of owning LTCI. Note also that higher educated individuals are more likely to have a LTCI (potentially the wealth effect mentioned by Mellor (2001)). Distance from the nearest child is negatively related to LTCI ownership, which contradicts the hypothesis that the lower availability of informal care should lead to an increase in the probability to own a LTCI, although the magnitude of the effect is very small. Note that distance from the children may be endogenous and we cannot discard the possibility that the model may suffer from an omitted variable bias. Further analysis will be necessary in order to shed light on this result. 
Table 33.4: Probability of owning private voluntary long-term care insurance

\begin{tabular}{|c|c|c|c|c|c|c|}
\hline Variables & $\begin{array}{l}\text { (1) Probit } \\
\text { Marginal } \\
\text { effects }\end{array}$ & $\begin{array}{l}\text { Standard } \\
\text { error }\end{array}$ & $\begin{array}{l}\text { (2) Probit } \\
\text { Marginal } \\
\text { effects }\end{array}$ & $\begin{array}{l}\text { Standard } \\
\text { error }\end{array}$ & $\begin{array}{l}\text { (3) Probit } \\
\text { Marginal } \\
\text { effects }\end{array}$ & $\begin{array}{l}\text { Standard } \\
\text { error }\end{array}$ \\
\hline Number of sons & $-0.002^{\star \star}$ & $(0.001)$ & $-0.003^{\star \star}$ & $(0.001)$ & $-0.005^{\star \star}$ & $(0.002)$ \\
\hline Number of daughters & $-0.003^{\star *}$ & $(0.001)$ & $-0.004^{\star \star \star}$ & $(0.001)$ & $-0.007^{\star \star \star}$ & $(0.002)$ \\
\hline Having a partner & -0.004 & $(0.003)$ & $-0.008 * \star$ & $(0.003)$ & 0.001 & $(0.005)$ \\
\hline One child in $\mathrm{HH}$ & - & - & $-0.006^{\star}$ & $(0.003)$ & $-0.009^{\star}$ & $(0.005)$ \\
\hline $\begin{array}{l}\text { Distance from the } \\
\text { nearest child }\end{array}$ & & & & & & \\
\hline$(\mathrm{km} / 100)$ & - & - & $-0.002^{\star \star}$ & $(0.001)$ & $-0.004^{\star}$ & $(0.002)$ \\
\hline Disability & $-0.004^{\star \star \star}$ & $(0.001)$ & $-0.005^{\star \star \star}$ & $(0.001)$ & -0.002 & $(0.002)$ \\
\hline Female & -0.001 & $(0.002)$ & -0.001 & $(0.003)$ & -0.002 & $(0.005)$ \\
\hline Low education & Ref. & Ref. & Ref. & Ref. & Ref. & Ref. \\
\hline Medium Education & 0.002 & $(0.003)$ & 0.002 & $(0.003)$ & 0.002 & $(0.006)$ \\
\hline High Education & $0.016^{\star \star \star}$ & $(0.004)$ & $0.017^{\star \star \star}$ & $(0.004)$ & $0.024^{\star \star \star}$ & $(0.007)$ \\
\hline Aged 50-64 & $-0.007^{\star \star}$ & $(0.003)$ & $-0.005^{\star}$ & $(0.003)$ & - & - \\
\hline Aged 65-74 & Ref. & Ref. & Ref. & Ref. & - & - \\
\hline Aged $75-84$ & $-0.008^{\star \star}$ & $(0.003)$ & $-0.008^{\star \star}$ & $(0.004)$ & - & - \\
\hline Aged $85+$ & $-0.014^{\star \star \star}$ & $(0.005)$ & $-0.013^{\star \star}$ & $(0.005)$ & - & - \\
\hline Observations & \multicolumn{2}{|c|}{33,756} & \multicolumn{2}{|c|}{26,911} & \multicolumn{2}{|c|}{10,931} \\
\hline Log likelihood & \multicolumn{2}{|c|}{$-8,565$} & \multicolumn{2}{|c|}{$-6,794$} & \multicolumn{2}{|c|}{$-2,794$} \\
\hline
\end{tabular}

Significance: ${ }^{\star \star \star}=1 \% ;{ }^{\star \star}=5 \% ;{ }^{*}=10 \%$

Notes: Country dummies are also included in the model; The first column presents the results of the model using the full sample, the second column only includes individuals with at least one child living out of the household, and the third column is restricted to individuals with at least one child living out of the household and being less than 65 year-old Source: SHARE Wave 5 release 0

The results also show that disability (and so being a potentially dependent person according to the created index by PCA) is associated with a lower probability to have a private voluntary LTCI. Furthermore, age is negatively associated with LTCI ownership, possibly due to cohort effect (the market for LTCI is still new, older cohorts are thus less likely to have one). Finally, gender does not seem to have an impact on LTCI ownership. In order to deal with the question of age, the third model (3) only includes people less than 65 years old with at least one child living outside of the household. The role of the number of children remains determinant (daughters are slightly better substitutes than sons and their coefficients are both higher than in the second model). By contrast, having a partner does not seem to influence insurance ownership and the estimate of the impact of disability decreases and is no longer significant. 
We have also tested the sensitivity of our results to different sample selections and specifications. The sample was, inter alia, restricted to the five countries with a declared rate of private voluntary LTCI higher than ten per cent. Indeed, the markets in Italy, Czech Republic, Denmark and Austria are really small (less than $2.5 \%$ ) because new. In this case, the results are even significantly stronger. Wealth and income were included in the analysis based on W4 values. While higher income tends to increase probability of insurance ownership, wealth does not seem to have an influence (maybe due to the fact that we are using data from W4 on a sub-sample of people who have participated to the fourth wave) and in all cases, the same negative impact of the number of children and presence of a child in the household on owning LTCI is significant, suggesting that family acts as a substitute for LTCI ownership. "Trust into family solidarity" (Pestieau \& Ponthière 2010) definitely plays a role.

\subsection{Trust in family solidarity plays a role}

In this chapter, we shed light on the relationship between the LTCI ownership and the availability of potential informal caregivers in European countries, focusing on the role of children. We find that having children, and especially a daughter, is associated with a higher probability of receiving informal care and with a lower probability to own a LTCI. Having a co-resident child is also negatively related to LTCI ownership. Given the decrease in fertility and the increasing labour force participation of women, we may expect that it will reduce the availability of potential informal caregivers that may lead to an increase in the demand for LTCI in the future.

\section{References}

Bolin, Kristian, Lindgren, Björn, Lundborg, Petter (2008): “Informal and formal care among single-living elderly in Europe”. In: Health Economics 17, p. 393-409.

Bonsang, Eric (2009): "Does informal care from children to their elderly parents substitute for formal care in Europe?”. In: Journal of Health Economics 28, p. 143-154.

Brown, Jeffrey, Finkelstein, Amy (2007): "Why is the market for long-term care insurance so small?”. In: Journal of Public Economics 91, p. 1967-1991.

Colombo, Francesca, Llena-Nozal, Ana, Mercier, Jérôme, Tjadens, Frits (2011): “Help wanted? Providing and paying for long-term care". In: OECD Health Policy Studies, OECD Publishing.

Courbage, Cristophe, Roudaut, Nolwenn (2011): “Long-term care insurance: the French example”. In: European Geriatric Medicine 2, p. 22-25. 
European Union (2012): The 2012 ageing report. Joint Report prepared by the European Commission (DGECFIN) and the Economic Policy Committee (AWG).

Mellor, Jennifer (2001): “Long-term care and nursing home coverage: are adult children substitutes for insurance policies?”. In: Journal of Health Economics 20, p. 527-547.

Pauly, Mark (1990): “The rational nonpurchase of long-term care insurance". In: Journal of Political Economy 98. No.1, p. 153-168.

Pestieau, Pierre, Ponthière, Grégory (2010): “Long term care insurance puzzle”. In: Working Paper $N^{\circ} 2010$ - 14. Paris: PSE.

Pinquart, Martin, Sörensen, Silvia (2003): "Differences between caregivers and non-caregivers in psychological health and physical health: a meta-analysis". In: Psychology and Aging 18. No.2, p. 250-267.

Van Houtven, Courtney, Coe, Norma, Skira, Meghan (2013): “The effect of informal care on work and wages". In: Journal of Health Economics 32. No.1, p. 240-252. 
